\title{
THE EUROPEAN PARLIAMENT AMBASSADOR SCHOOL PROGRAMME (EPAS) AT GIMNAZIJA NOVA GORICA, SLOVENIA
}

\section{PROGRAM "ŠKOLA AMBASADOR EUROPSKOG PARLAMENTA" U GIMNAZIJI „NOVA GORICA“, SLOVENIJA}

\author{
Martina Kobal \\ „Nova Gorica" Highschool, Nova Gorica, Slovenia \\ Srednja škola "Nova Gorica“, Nova Gorica, Slovenija
}

\section{Abstract}

This paper will focus on the European Parliament Ambassador School Programme, whose aim is to create a permanently increasing network of schools across the European Union. Gimnazija Nova Gorica became part of the network in 2016, and since then the school has engaged with the Slovenian European Parliament Liaison Office, the European Parliament and its Members, and has carried out teaching activities that raise awareness of Europe, European democracy and citizenship at large. This paper will also demonstrate various activities and events organized by Junior Ambassador students at Gimnazija Nova Gorica and their mentors. Not only does the European Parliament Ambassador School Programme enable students to develop critical thinking, teamwork and problem-solving skills, but it also helps participants raise concerns about issues concerning the European Union and develop their ideas for a better Europe in the context of multilingualism and multicultural EU policy.

\section{Sažetak}

Članak se usredotočuje na program "Škola ambasador Europskog parlamenta", koja ostvaruje razvijajuću se mrežu škola ambasadorica u Europskoj uniji. Gimnazija Nova Gorica uključuje se u program 2016. godine i sve od tada izvodi obrazovne djelatnosti u stalnoj suradnji sa Uredom Europskog parlamenta u Sloveniji, Europskim parlamentom te njegovim predstavnicima - europskim zastupnicima. Projekt je prije svega namijenjen osvješćivanju mladih o Europi, europskoj parlamentarnoj demokraciji i europskom državljanstvu. Pored toga u članku su predstavljeni različiti događaji i aktivnosti, koje su mladi ambasadori zajedno sa mentoricama organizirali u Gimnaziji Nova Gorica. Program "Škola ambasador Europskog parlamenta" ne samo da učenicima omogućuje razvijanje vještina kritičnog mišljenja, sudjelovanja i rješavanja problema, već i pripomaže $\mathrm{k}$ tome, da se učenici suočavaju sa problemima s kojima se Europska unija suočava, te traže rješenja koja bi pripomogla k tome, da bi buduća Europa postala takvom, kakvom si želimo u kontekstu višejezičnosti i višekulturnosti. 


\section{Introduction}

Gimnazija Nova Gorica is a co-educational secondary school for students aged 15 to 19, situated in the west of Slovenia near the Italian border. The school has participated in the European Parliament Ambassador School Programme since September 2016 and it is officially certified as one of the best European Parliament Ambassador Schools in Slovenia.

The European Parliament Ambassador Schools Programme (EPAS) is a network of schools across the European Union whose aim is to raise awareness amongst young people in secondary education of the impact of the European Union in their daily lives. In Slovenia the programme is comprised of nearly 600 Slovenian youngsters and is implemented by the Slovenian European Parliament Liaison Office.

Gimnazija Nova Gorica's active participation in the European Parliament Ambassador School Programme has been a truly memorable experience for all the students and teachers alike. The three Senior Ambassadors (teachers) who are in charge of the project, Suzana Černe, Head of EPAS, Anastazija Makorič Bevčar and Martina Kobal, see the programme as an excellent way to get and share ideas about teaching and about the European Union.

Students at Gimnazija Nova Gorica are eager to learn about European parliamentary democracy, political choices and European citizenship values. Every year they participate in the Euroscola programme Competition and have won first prize several times, the prize being a subsidised trip to Strasbourg to represent Slovenia at Euroscola, where young people from the $28 \mathrm{EU}$ Member States become Members of the European Parliament for one day. There are more than thirty students who aim to acquire the title of Junior European Parliament Ambassadors every year.

\footnotetext{
${ }^{8}$ European Day of Languages https://ec.europa.eu/info/news/european-day-languages-2019-2019sep-02 en
}

\section{Ready, Steady, Action!}

Students at Gimnazija Nova Gorica are actively involved in different activities and events related to the European Parliament Ambassador School Programme (see https://ambasadorjiep.wixsite.com/mysite).

The following events represent some of the programme's highlights :

- Every year the students organise the celebration of the European Day of Languages ${ }^{8}\left(26^{\text {th }}\right.$ September), since "cultural and linguistic diversity and multilingualism are key principles of the Europena Union" /1/. The event called 'Language Café' is jointly organised by Gimnazija Nova Gorica and Europe Direct, Regional Development Agency of Northern Primorska Ltd Nova Gorica. The students try to teach the customers and passers-by some phrases and words in different foreign languages. Foreign languages are an integral part of the school curriculum at Gimnazija Nova Gorica. Students learn English as their first foreign language and they can choose among French, German, Italian, Spanish or Russian for their second foreign language. The general objectives of the European Day of Languages are "alerting the public to the importance of language learning, promoting the rich linguistic and cultural diversity of Europe, and encouraging lifelong language learning in and out of school, whether for study purposes, for professional needs, for purposes of mobility or for pleasure and exchanges" (Council of Europe).

- In November 2017 the Junior Ambassadors were actively involved in 'The Europe We Want' event, organised by the European Grouping of Territorial Cooperation (EGTC). The students were asked to make an important contribution to the scenarios outlined in the White Paper on the Future of Europe. The Junior Ambassador students presented their views on how the scenarios, 
offered by the White Paper, would affect the lives and work of the young. They also participated in the discussion and had a say in cross-border policies and the presentation of cross-border projects regarding Slovenia and Italy.

- Every May the Junior Ambassadors organise a Europe Day event to celebrate peace and unity in Europe.

The Junior and Senior Ambassadors, teachers of Gimnazija Nova Gorica, Head of Unit and other representatives from the European Parliament Liaison Office in Slovenia and the Faculty of Social Sciences, as well as other guests gathered at Europe Square on the border between Nova Gorica (Slovenia) and Gorizia (Italy), which honours the accession of Slovenia to the European Union, in order to be a part of the Living Flag of Europe. The participants stood in the right spots to raise the blue strips and twelve yellow stars and form the Flag of Europe in celebration of Europe Day ( $9^{\text {th }}$ May). The flag symbolically represented the fact that if we work together $\mathrm{co}^{-}$ operatively, we can achieve significant goals despite our differences.

The celebration of Europe Day in 2018 was marked by multilingualism. Is multilingualism in Europe a luxury? Mavrič and Kučiš /2/ argue that "we should not regard multilingualism as a luxury, but as a necessity for the very existence of the European Union". Our Guest Speaker at the event was Mr Valter Mavrič, Director of Translation and acting Director-General of DG Translation at the European Parliament. His expertise and experience in this field of work was an excellent addition to our European Parliament Ambassador School Programme and the Junior Ambassadors conducted an interview on the topic of multilingualism and translation, which was of great benefit for the students. Mavrič pointed out:

The principle of multilingualism [in the European Parliament] means that all legislation is available in all the official languages, currently 24 , and enables all citizens - whether they be Members of the European Parliament (MEPs), journalists or schoolchildren - to follow the legislative work of the European institutions. In the European Parliament, MEPs have the right to speak, read, write and listen in their own language. Observing this multilingualism at work in the European Parliament is a truly unique experience, which everyone can follow when parliamentary part-sessions and committee meetings are streamed on the internet and broadcast. At the same time, the relevant documents are readily available in all the official languages and can be found on the European Parliament website. /3/

As the authors claim, "multilingual communication among European citizens is a very important segment in the formation of a European identity" /4/.

At the invitation of Mr Valter Mavrič Gimnazija Nova Gorica recorded a radio programme for Europarl Audio Capacity, a web-based audio channel, which aims at audiences with different programmes and podcasts. Eight candidates for Junior Ambassadors offered the audience an insight into some of the highlights of the European Parliament Ambassador Schools Programme at Gimnazija Nova Gorica. The audio texts were recorded in Slovenian, English, French, Italian and German and the programme was broadcast on $13^{\text {th }}$ and $14^{\text {th }}$ May 2018.

In May 2019 the Junior Ambassadors were actively involved in \#thistimeimvoting campaign and they showed great enthusiasm and dedication in promoting the elections. They organised 'This Time I am Voting' Café, which proved to be very successful. They also created their own logo 'Leave your Mark' for 2019 European Parliament elections and printed T-shirts and shopping bags with this logo. The T-shirts and bags were distributed to the public during the event.

- $\quad$ The Junior Ambassadors set up an EU Info Point in the school library, where students and visitors can get information and learn a lot about the European Union. The Info Point has a wide selection of publications and brochures, magazines and newspapers that bring the European Union and its institutions closer to the reader. 


\section{Main Benefits of EPAS}

Stimulation, innovation and interaction lie at the heart of the European Parliament Ambassador School Programme, therefore the project has been beneficial in many ways. It enables Junior Ambassadors to do research on the European Union and learn about European parliamentary democracy and values. The project is a great opportunity for young people to be active, have their voices heard, and participate in their community.

The European Parliament Ambassador School Programme helps students develop critical thinking, teamwork and problem-solving skills, along with the ability to communicate effectively with others. Junior Ambassador students engage in workshops, debates and various activities with their peers and also European decision-makers. Moreover, Junior Ambassadors raise concerns about issues concerning the European Union and develop their ideas for a better Europe. Finally yet importantly, the programme also helped to bring the European Union and the vital importance of voting in the 2019 European elections closer to first-time voters.

The saying goes, "the plan is to fan this spark into a flame" $/ 5 /$, and this is exactly how the European Parliament Ambassador School Programme results in real change, as it is interdisciplinary, collaborative and motivating, and the contributions of young people are heard by policy makers and politicians throughout Europe.

What is more, the programme meets Senior Ambassador's expectations. It is a popular and noble aspiration for educators to inspire and develop empowered learners, innovative designers, creative communicators, and global collaborators. Undeniably, by joining the programme, students get involved and plant the seeds of many lasting ideas. In addition, they start their journey towards creating the future of the European Union. As Klaus Welle, Secretary-General of the European Parliament, put it, "Europe needs your participation, your energy and enthusiasm more than ever, but it also ne- eds your creativity and your innovation. The future of the EU belongs to you, the young generation" (EYE2018 7).

\section{Students' Comments}

Anastasija Knez, Junior Ambassador:

I am very happy and honored to have been a part of that project, because it has undoubtedly given me a lot of new knowledge and experience.

If I had a chance I would definitely participate in that kind of project again. Not only did I get to know my school mates and their interests better, but I also learned how to interact with other people, sell them my ideas and listen to their opinions. The thing that I enjoyed most was our excursion to Brussels, because not everyone can visit the European Parliament, meet a MEP in person and see beautiful places in OUR Europe.

Nika Vrabec, Junior Ambassador:

Being a Junior Ambassador is the best experience every student can get. You have a chance to get to know the EU better: it gives you an opportunity to learn about the institutions of the EU and EU legislation, and most importantly, about democracy and freedom of choice. It encourages you to become an active citizen of the EU.

Julija Baša, Junior Ambassador in charge of photography and video-making:

I have gained a lot from EPAS. I immensely enjoyed the feeling of working together in a connected team, in which everyone strove to accomplish their task. There was a motivational atmosphere and everything I did, I did with pleasure. I liked the fact that there was so much going on and that every task we had to face was a new exciting challenge. 


\section{Concluding Remarks}

The European Parliament Ambassador Schools Programme started off at Gimnazija Nova Gorica not only as an idea to be awarded an EPAS plaque, but also to encourage students to become active citizens in a democratic and mulitlingual Europe. The project became a huge part of our school and we met the challenge. Every year a number of enthusiastic and dedicated Junior Ambassadors receive a Junior Ambassador Certificate. What is even more important, at the end of the school year Junior Ambassadors are aware of the fact that they can be the strongest force in shaping the future of Europe with their ideas and their actions in the context of promoting multiculturalism and linguistic diversity $/ 6 /$. Our aim is to consolidate the project in the future and to take a step further by applying for the EU4Youth project. Participation in EU4Youth opens great opportunities for both students and teachers to acquire valuable skills in communication, writing, video-making and team building while deepening the students' knowledge about the European Union. The project gives young committed students an excellent opportunity to exchange their fresh ideas with their European peers and to present their vision of a future Europe. "The EP is not 751 individuals but 508 million voices, roaring for the future we want for Europe, our home" (European Parliament, Liaison Office in Ireland).

Notes

/1/ Kučiš, V., Majhenič, S. (2018). Cultural and stressrelated manifestations of political controversial language in the European Parliament from the view of interpreters. Babel, 2018, vol. 64, 1, pp. 33-62.

/2/ Mavrič, V., Kučiš, V. (2018). Multilingualism and translation as a communication challenge at the European Parliament. Transkulturalität im mehrsprachigen Dialog = Transcultural communication in multilingual dialogue. (Translatologie Bd. 17). Edited by V. Kučiš. Hamburg: Dr. Kovač. 2018, pp. 47-67.

/3/ Ibid.

/4/ Ibid.
/5/ Miranda, Lin-Manuel. "My Shot". Hamilton. 29 Oct. 2015, https://lyricstranslate.com/en/lin-manuel-miranda-anthony-ramos-daveed-diggs-okieriete-onaodowan-leslie-odom-jr-lyrics.html. Accessed 10 Sept. 2019.

/6/ Kučiš, V. (2016). Translatologija u teoriji $i$ praksi. Zagreb: Nonacom

Literature

1. Council of Europe. "What is the European Day of Languages?". https://edl.ecml.at/Home/Whatisit/tabid/1760/language/en-GB/Default.aspx. Accessed 10 Sept. 2019.

2. DGT (2009) Frequently asked questions about DGT. $\quad$ http://ec.europa.eu/dgs/translation/faq/index_en.htm. Accessed 10 Sept. 2019.

3. European Day of Languages (2019) https://ec.europa.eu/info/news/europeanday-languages-2019-2019-sep-02 en. Accessed 10 Sept. 2019.

4. European Parliament, Information Office in Ireland. "What is the European Parliament Ambassador School Programme?". http://www.europarl.europa.eu/czechrepublic/resource/static/files/ambassadorschool-leaflet en-bez-log.pdf. Accessed 8 Sept. 2019.

5. European Parliament, Liaison Office in Ireland. "Ambassador School Programme". http://www.europarl.europa.eu/ireland/en/youth-outreach/ambassadorschool-programme. Accessed 8 Sept. 2019.

6. Schuetz, Robert. "Project-Based Learning: Benefits, Examples, and Resources". Schoology Exchange, 1 June 2018, $\quad$ https://www.schoology.com/blog/project-based-learningpbl-benefits-examples-and-resources. Accessed 10 Sept. 2019.

7. Welle, Klaus. "Foreword". EYE2018 Programme, 1-2 June 2018 - Strasbourg. Strasbourg: European Parliament, 2018. 